\title{
Perennial pigeonpea: a multi-purpose species for agroforestry systems*
}

\author{
J.N. DANIEL and C.K. ONG \\ International Crops Research Institute for the Semi-Arid Tropics, \\ Patancheru, Andhra Pradesh 502324, India
}

Key words: Agroforestry, fodder, genotype, grain yield, perennial pigeonpea, soil fertility

\begin{abstract}
Perennial pigeonpea is receiving considerable attention in India as a multi-purpose species for agroforestry systems. Its multiple uses include food, fodder, manure and firewood. Data on perennial pigeonpea, together with relevant information on shorter-duration genotypes, are reviewed in this paper.

Growth of perennial pigeonpea, like that of medium-duration grain types (150 to 190 days) in intercropping systems with cereals, is slow during the first 3 to 4 months. Therefore, it requires minimum sacrifice in terms of yield of annual crops in the system during the first year and offers many of the benefits of tree species in subsequent years. Total dry matter production potential of perennial pigeonpea in peninsular India is more than $15 \mathrm{tha}^{-1}$ year ${ }^{-1}$ consisting of about $2.0 \mathrm{t}$ of grain, $3.0 \mathrm{t}$ of leaf litter, $9.0 \mathrm{t}$ of stems and $1.0 \mathrm{t}$ of residue made up of podwalls and twigs. In addition, pigeonpea improves soil fertility by nutrient cycling and biological nitrogen fixation. Susceptibility of pigeonpea to diseases and negative effects on growth of annual crops are the potential constraints in the semi-arid tropics. Some pertinent areas for further research are proposed.
\end{abstract}

\section{Introduction}

A major constraint to the adoption of agroforestry systems in the semi-arid tropics is the severe competition between trees and crops for environmental resources. Mean grain yield reductions of more than $60 \%$ in annual crops have been reported in leucaena-based alley cropping systems [29]. In addition, tree species including leucaena are notoriously slow in giving economic returns because of poor growth rate during the year of planting. In contrast, intercropping studies have consistently shown that pigeonpea (Cajanus cajan (L.) Millsp.) tolerates severe shading and offers minimal competition to fastgrowing crops, but is able to recover from and compensate for the slow early growth [35]. Pigeonpea was a promising crop during the early part of this century in Hawaii and was sometimes managed as a perennial crop for grain and

\footnotetext{
* Submitted as ICRISAT Journal Article No. 917 for 'Agroforestry Systems'.
} 
forage [16]. Though intrinsically perennial [5], pigeonpea is grown as a perennial crop (that is, more than 12 months) only in backyards, around annual crops, on field bunds, or as boundary plants [3,15,27]. Despite the potential to produce food, fodder and firewood, the use of pigeonpea as the perennial component in agroforestry systems is under-exploited.

Perennial pigeonpea is similar to the medium-duration types ( 5 to 7 months) except for the longer duration to flowering and maturity, lower harvest index, greater ratoonability and deeper rooting habit. The perennial nature enables it to withstand harsh environmental conditions and recover after the removal of stresses. It is an attractive choice for smallholders because an edible grain yield is not commonly obtained from agroforestry species.

The International Crops Research Institute for the Semi-Arid Tropics (ICRISAT) in Hyderabad, India has the global germplasm collection for pigeonpea and suitable perennial genotypes have been identified for agroforestry uses. This paper reports on the results of preliminary trials started in 1985 with these materials and reviews the relevant information with the objective to stimulate interest in research on perennial pigeonpea as an agroforestry species. Due to the limited information available on perennial pigeonpea in agroforestry systems, data from genotypes grown mainly for grain, irrespective of growth duration, are often cited in this review.

\section{Species characteristics}

\subsection{Environmental requirements}

Pigeonpea is adapted to tropical and sub-tropical environments extending between $30^{\circ} \mathrm{N}$ and $30^{\circ} \mathrm{S}$ latitudes [28]. India, eastern Africa, central and south America and the Caribbean are major pigeonpea-producing regions. Bulk of the grain pigeonpea is grown in annual cropping systems of about seven months duration, most frequently as an intercrop with cereals. Pigeonpea has the hardiness to produce at least some grain yield under adverse conditions and make use of the residual moisture very efficiently [35]. Moreover, it grows satisfactorily even under the combined stress of drought and poor soil fertility [13].

Pigeonpea is grown in a wide range of agro-ecological situations and the cropping season for annual grain types normally avoids long drought and frost incidence. Since this is not possible in a perennial system, pigeonpeabased agroforestry systems cannot be adopted under certain environments. Areas prone to frost incidence and water logging are not suitable for 


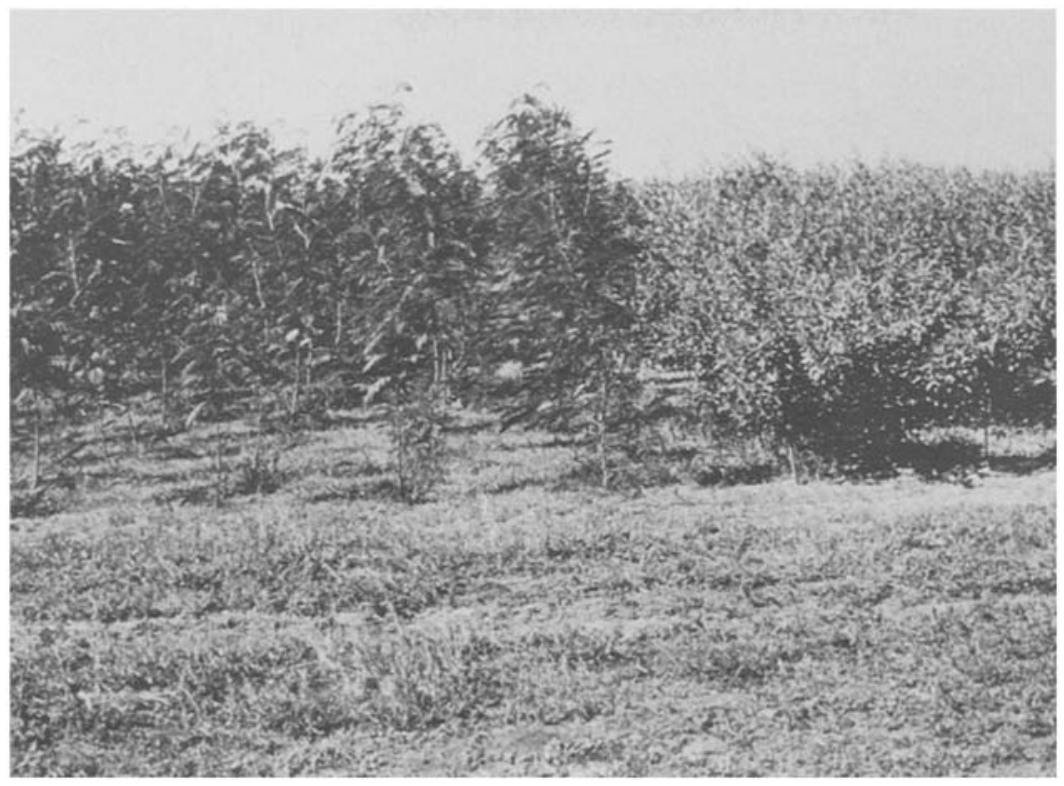

Fig. I. Six-month old perennial pigeonpea (right) and leucaena on Alfisol. ICRISAT Center.

pigeonpea [16,33]. The soil must have high water holding capacity to enable perennial pigeonpea to withstand the dry season. Timeliness of major events - especially planting, fodder harvests and pod harvests - is essential to match the environmental requirement of pigeonpea with seasonal changes in relation to temperature and photoperiod.

\subsection{Growth and yield potential}

Information on dry matter production and distribution vary widely probably due to the differences in genotype, environment and management. Initial growth and canopy development of perennial pigeonpea is so slow that light interception at 30 days after sowing was less than $10 \%$, and was only about $50 \%$ at 60 days [C.K. Ong, unpublished]. This is similar to the values reported for medium-duration genotypes where the lag phase of pigeonpea is taken advantage of in many cropping systems to include faster growing crops like sorghum [35]. In spite of the slow canopy establishment, growth of pigeonpea was greater than leucaena in the first year in studies at ICRISAT (Fig. 1) and at IITA [11].

Total above-ground dry matter production was more than $15 \mathrm{tha}^{-1}$ in several early-maturing pigeonpea genotypes at Hisar in northern India [10]. The yield of rainfed perennial pigeonpea exceeds that of the most productive sorghum/pigeonpea intercropping system which varied from 8.0 to $10 \mathrm{tha}^{-1}$ 
at ICRISAT center (Piara Singh, unpublished). Harvest index of traditional grain pigeonpea varieties is below $20 \%$ and consequently the grain yield is only about $0.7 \mathrm{tha}^{-1}$. Allocation of assimilate towards grain is lower in perennial genotypes compared to annual types [21]. Nevertheless, several perennial pigeonpea genotypes with grain yield potentials of more than $2.0 \mathrm{tha}^{-1}$ have been identified at ICRISAT [9].

\subsection{Genetic variation}

The genotype range of pigeonpea extends from long duration to extra-short duration types that mature within 90 days [9]. Long-duration genotypes require about seven months for their first grain harvest, and repeat the growth cycle annually for several years. Thus, pigeonpea is a versatile plant that can be utilized, depending upon genotype and management, as a short-season annual in monocropping systems, as a residual-moisture utilizer in intercropping systems with cereals, or as a perennial in agroforestry systems.

Availability of genotypes of appropriate phenology and morphology for the perennial system is a basic requirement. Perennial pigeonpea in an agroforestry system would be subjected to one or more dry periods. Therefore, it should be able to withstand high temperature, low moisture availability, and incidence of pests and diseases, especially fusarium wilt and sterility mosaic disease. Several genotypes showing resistance to these stresses are being evaluated presently at ICRISAT center. Plant mortality in genotype ICP 8094 was $12 \%$ and $44 \%$, respectively, at the end of first and second year. If the plant population is reduced during the second year, either due to plant mortality or as a management strategy, the branches of surviving plants should spread out to compensate for the lower population. A comparison of six perennial pigeonpea genotypes at ICRISAT [9] showed that the genotype ICP 8094 yielded more grain than others because of its bushy, spreading habit. However, preliminary observations from alley cropping trials at the same location showed that erect types are considerably less competitive than ICP 8094, probably due to their deep-rooting habit. Studies in Hawaii showed that erect-branching genotypes of pigeonpea produced deep-penetrating roots whereas roots of spreading types were dense and shallow [16]. An erect or semi-spreading type may be preferred for systems where light is a limiting factor for the annual crop.

\subsection{Diseases and pests}

Susceptibility to fusarium wilt and sterility mosaic disease limited the utilization of pigeonpea as a perennial species. Plant mortality of about $75 \%$ due 
to fusarium wilt was observed after the second year in Malawi (S.A. Materechera, unpublished). Prospects for pigeonpea-based agroforestry systems have recently brightened with the advent of genotypes that combine resistances to these diseases. Diseases of minor importance can become more serious when the plant becomes less vigorous because of ageing. New diseases such as macrophomina blight can also become more important. Older wood and decaying roots may attract disease and pest problems as well.

The major pest in pigeonpea is the pod borer Helicoverpa armigera. This pest can cause substantial reduction in grain yield as the affected pods can at times exceed $80 \%$ [8]. The height and the dense canopy of perennial pigeonpea poses a problem in pesticide spraying. In addition, the presence of another host in the system, such as chickpea, can further complicate the pest management strategy, although this has not yet been a problem at ICRISAT.

\section{Uses in agroforestry systems}

\subsection{General}

U'ses for almost all the parts of pigeonpea are cited in literature. Hence, any economic evaluation of perennial pigeonpea-based systems must consider the total yield by way of grain, leaf and stem. In addition, yield improvement in the subsequent crop resulting from enhanced soil fertility can not be ignored. Uses of different products obtained from pigeonpea are reviewed in detail by Wallis et al. [33]. Some of the essential aspects are given below.

\subsection{Seed and pod}

Perennial pigeonpea seeds have essentially the same seed quality as grain types. The dry split pea is the principal use of pigeonpea. Protein content of dry seeds is in the 20 to $30 \%$ range $[10,34]$ which makes it an important source of protein in the vegetarian diet in India. Pigeonpea flour can be a substitute for mung bean flour in bean noodle in Thailand [3]. Immature green seeds of pigeonpea can have the same uses as green peas (Pisum sativum) in east Africa, the Caribbean and some parts of India. For this purpose, pigeonpea varieties with large, sweet seeds are preferred [8]. Pods of vegetable pigeonpeas have to be long, sweet, green and contain about six seeds.

Although pigeonpea is mainly grown as a human food, seeds can also be 
used as animal feed [33]. Harvest trash, consisting of pod walls, leaf and stem residue, was of higher feeding value than pod alone [34].

\subsection{Leaf and stem}

Pigeonpea leaves can be used as fodder for farm animals [33]. Fodder yields in the range 3.5 to $6.0 \mathrm{tha}^{-1}$ have been obtained with 3 to 4 cuts at 25 and $50 \mathrm{~cm}$ heights. The in vitro digestibility of the foliage was between 41 and $69 \%$ and crude protein content was between 17 to $32 \%$ [2]. Preliminary studies on some promising perennial pigeonpea lines show that with irrigation they can produce 10 to $15 \mathrm{tha}^{-1}$ year ${ }^{-1}$ of green fodder in three harvests $[9,33]$. Pigeonpea fodder is usually available during the rainy season when fodder from other sources is plentiful. However, pigeonpea fodder, which has about 3.5\% nitrogen [12], can be mixed with low quality fodder to improve the feeding value. Leaves can also be used as a mulch or green manure [6].

Stems of pigeonpea are an important by-product at the time of harvesting. The air-dried stem yield from long-duration genotypes was about $7.5 \mathrm{tha}^{-1}$ season ${ }^{-1}$ at Gwalior, India [9]. The air-dry stem weight, excluding the main stem up to a height of $1.0 \mathrm{~m}$, obtained from perennial pigeonpea at ICRISAT center in the second year was $7.0 \mathrm{tha}^{-1}$; the weight of the main stem was $2.0 \mathrm{t} \mathrm{ha}^{-1}$. Total stem weights of 10 to $12 \mathrm{tha}^{-1}$ have been recorded in Malawi (S.A. Materechera, unpublished). In some areas of Northern India, wages for harvesting, threshing and bagging of pigeonpea is paid in the form of dried, threshed stems [14]. The main stem of pigeonpea is used as firewood and thin straight branches for thatching and basket making.

\subsection{Soil fertility improvement}

Perennial legume species are known for their potential to improve soil fertility through more efficient nutrient cycling and nitrogen fixation [19]. Being a deep-rooted plant, perennial pigeonpea can be expected to extract nutrients from deeper layers of soil and return to the surface layer through litter fall (Fig. 2). The nitrogen content of the pigeonpea leaf litter is about 1.3 to $1.5 \%$ [17] and a ton of fallen litter can contribute at least $10 \mathrm{~kg}$ of nitrogen. In perennial systems, litter will be available yearly and, if left in situ, only a fraction of the nutrients released through decomposition is likely to get into the soil. Therefore, full benefits are realized only if the litter is incorporated into the soil and sufficient time is allowed for the release of nutrients through decomposition. Litter can also be collected from pigeonpea area and added to other crop fields either as a mulch or incorporated as a crop residue. 


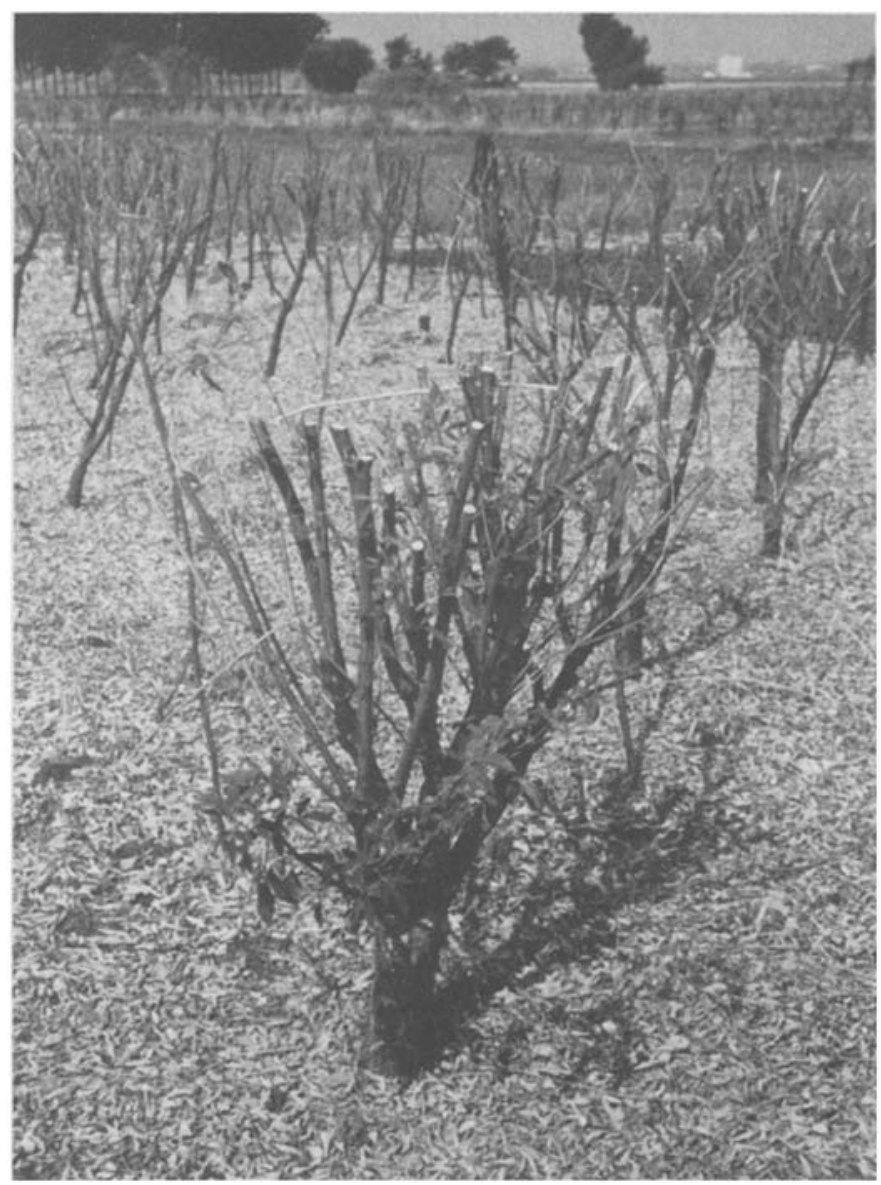

Fig. 2. Litter-fall in recently pruned (to $1.0 \mathrm{~m}$ ) perennial pigeonpea field at ICRISAT center.

The amount of litter added by pigeonpea will depend on the genotype and management practices. Litter from short and medium-duration pigeopea genotypes was less than $1.0 \mathrm{t} \mathrm{ha}^{-1}[8]$. Litter yield can be substantially higher in long-duration pigeonpea. A four-year pigeonpea fallow at IITA yielded $12.8 \mathrm{tha}^{-1}$ of air-dry matter excluding woody parts [12]. The quantity of litter will also depend on time of planting as it determines the vegetative phase of long-duration pigeonpea, a photosensitive genotype. A long-duration pigeonpea sown in June had a litter fall of $6.4 \mathrm{~kg} \mathrm{ha}^{-1}$ whereas the same genotype sown in September had only $2.4 \mathrm{~kg} \mathrm{ha}^{-1}$ in north India [25]. Litter yield from perennial pigeonpea in the second year was about $3.0 \mathrm{tha}^{-1}$ at ICRISAT center.

Biological nitrogen fixation is another benefit from pigeonpea. An 
increase in nitrogen fixation with crop duration has been reported [17]. A pigeonpea genotype maturing in 115 days fixed only $4.4 \mathrm{~kg}$ nitrogen $\mathrm{ha}^{-1}$ whereas a genotype reaching maturity in 215 days fixed almost $70 \mathrm{~kg} \mathrm{ha}^{-1}$. A large fraction of the fixed nitrogen is returned to the soil through litter, roots and nodules.

Fertility of soils where pigeonpea was grown is usually improved and this is reflected in the higher yields obtained from succeeding crops. The estimated residual nitrogen equivalent of a medium-duration pigeonpea ranged from 38 to $49 \mathrm{~kg} \mathrm{ha}^{-1}$ which resulted in 57 and $32 \%$ increases in grain and dry matter yields respectively in the succeeding maize crop [18]. Residual effects are likely to be greater in soils cropped to perennial pigeonpea for a longer period.

Grown as a green manure crop in root-knot infested areas, pigeonpea reduced the level of nematodes in the succeeding susceptible crops. However, there was no reduction in the level of sting nematodes [24]. Though evidence is not available, perennial pigeonpea would be expected to improve many soil physical and chemical fertility parameters as well.

\section{Management aspects}

\subsection{Spatial arrangement and plant density}

The interaction between the perennial species and the annual crops in agroforestry systems would reach a maximum in mixed plantings and would be minimum when they are separated spatially by planting in sole blocks. Plant arrangements that reduce competition between the two components, by reducing the area of interaction, often increase competition for resources among plants of the perennial species. As a result, growth and biomass accumulation of the perennial in block-planting is likely to be lower compared to that in mixed planting. Systems such as alley cropping with single or double-row hedges and strip-cropping are between the extremes of mixed and block plantings. Such arrangements would favour grain production in pigeonpea as flowers and pods are borne on branches exposed to sunlight.

A study at ICRISAT center on a shallow Vertisol with perennial pigeonpea genotype ICP 8094 showed that the number of flowering branches and number of pods in a plant in the middle of the stand were only $42 \%$ and $30 \%$ respectively of that of a hedgerow plant in the second year (Table 1). As a result, grain yield was substantially higher for the hedgerow plant compared to the one in the middle of the stand. Seeds per pod and seed weight vary relatively little within a genotype, so number of branches and pods per unit 
Table 1. Comparison of growth and yield parameters of perennial pigeonpea plant in the hedgerow with plant in the middle of the stand, ICRISAT Center

\begin{tabular}{|c|c|c|c|c|c|c|}
\hline \multirow[t]{2}{*}{ Parameter } & \multicolumn{3}{|c|}{ 1st year } & \multicolumn{3}{|c|}{ 2nd year } \\
\hline & Hedge & Middle & $\mathbf{L S}^{\mathrm{a}}$ & Hedge & Middle & $\mathrm{LS}^{\wedge}$ \\
\hline Height at flowering $(\mathrm{cm})$ & 219 & 227 & NS & 227 & 296 & NS \\
\hline $\begin{array}{l}\text { Stem diameter at } \\
\text { flowering }(\mathrm{mm})\end{array}$ & 25 & 26 & NS & 53 & 40 & $*$ \\
\hline $\begin{array}{l}\text { Flowering branches per } \\
\text { plant }^{\text {b }}\end{array}$ & 21 & 14 & $*$ & 148 & 63 & $* *$ \\
\hline Pods per plant & 269 & 190 & $* *$ & 3035 & 905 & $* *$ \\
\hline Grain yield per plant $(\mathrm{g})$ & 59 & 40 & $* *$ & 515 & 149 & $* *$ \\
\hline Time of flowering & & $15 / 12 / 87$ & & & $25 / 10 / 88$ & \\
\hline Percentage mortality & 12 & 12 & & 18 & 44 & \\
\hline
\end{tabular}

"Level of significance: difference between the treatments is not significant (NS), significant at $1 \%\left({ }^{* *}\right)$, or at $5 \%\left({ }^{*}\right)$ level.

${ }^{h}$ Primary branches only for first year and total branches for second year.

area determine grain yield $[1,7]$. Plants in the middle of the stand tended to be taller than those in the hedgerow probably due to competition for light, but the stems of the hedgerow plants were significantly thicker in the second year (Table 1). As a result, the hedgerow plants yielded more stems than those in middle rows.

Alley cropping, though a promising system for the humid tropics, has limitations in the semi-arid tropics where moisture deficit is a major constraint [29]. Modifications in alley arrangement, such as increasing the alley width, may reduce the annual crop area facing competition from the hedgerow and increase the benefits from the system. However, this may result in the reduction in number, and thereby yield, of perennials per unit area. Studies at the International Institute of Tropical Agriculture (IITA) indicated that leaf and nitrogen yields of pigeonpea, leucaena and tephrosia decreased by about $65 \%$ when alley widths were increased from 2.25 to $6.75 \mathrm{~m}$ [11]. Combining the perennial hedgerows to form strips, that is, increasing hedge width, will increase the alley width without a corresponding reduction in the number of perennial plants per unit area.

A comparison of block-planting of perennial pigeonpea with strip-planting - strips of $4.0 \mathrm{~m}$ width alternating with $8.0 \mathrm{~m}$ wide strips for annual crops - is being investigated at ICRISAT presently on a shallow Vertisol with genotype ICP 8094 (Fig. 3). Density in both planting arrangements is 10,000 plants ha ${ }^{-1}$. Results of this study show that dry matter production from the area under perennial pigeonpea $(0.33$ ha as per the $1: 2$ perennial:annual arrangement) was $5.10 \mathrm{t}$ in block-planting which is equivalent to $15.3 \mathrm{tha}^{-1}$ (Table 2). The equivalent grain yield from block-planting was 


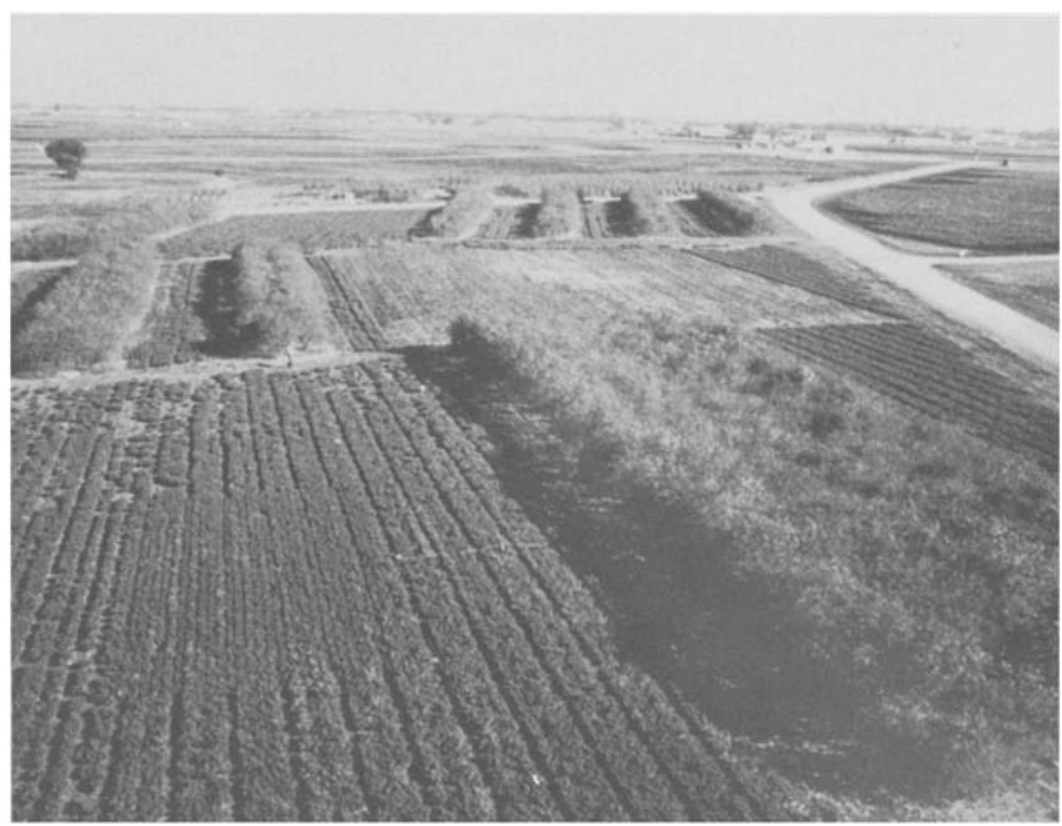

Fig. 3. Perennial pigeonpea grown in block- (right foreground) and strip-planting with chickpea on Vertisol, ICRISAT center.

Table 2. Dry matter production and yield in block and strip arrangements when a ha of land was planted to perennial pigeonpea and annual crops in a 1:2 ratio, ICRISAT center

\begin{tabular}{lrrll}
\hline Parameter & Block & Strip & LS $^{\text {a }}$ & B:S ratio \\
\hline A. $\quad$ Maximum dry matter (t) & & & & \\
$\quad$ Chickpea (1st year) & 1.36 & 1.01 & NS & 1.35 \\
$\quad$ Chickpea (2nd year) & 1.75 & 0.84 & $* *$ & 2.08 \\
$\quad$ Sunflower & 3.35 & 2.56 & $*$ & 1.31 \\
$\quad$ Pigeonpea (2nd year) & 5.10 & 7.43 & $*$ & 0.69 \\
$\quad$ Total & 11.56 & 11.84 & NS & 0.98 \\
B. $\quad$ & & & \\
$\quad$ Grain yield (t) & & & & \\
$\quad$ Chickpea (1st year) & 0.64 & 0.52 & NS & 1.23 \\
$\quad$ Chickpea (2nd year) & 0.93 & 0.34 & $* *$ & 2.76 \\
$\quad$ Pigeonpea (1st year) & 0.14 & 0.17 & $*$ & 0.82 \\
$\quad$ Pigeonpea (2nd year) & 0.68 & 1.24 & $* *$ & 0.55 \\
$\quad$ Total & 2.39 & 2.27 & NS & 1.05 \\
\hline
\end{tabular}

${ }^{a}$ Level of significance: difference between the treatments is not significant (NS), significant at $1 \%\left({ }^{* *}\right)$, or at $5 \%\left({ }^{*}\right)$ level.

${ }^{\mathrm{b}}$ Block:strip ratios of $1>$ and $1<$ indicate advantages for strip and block arrangements respectively. 


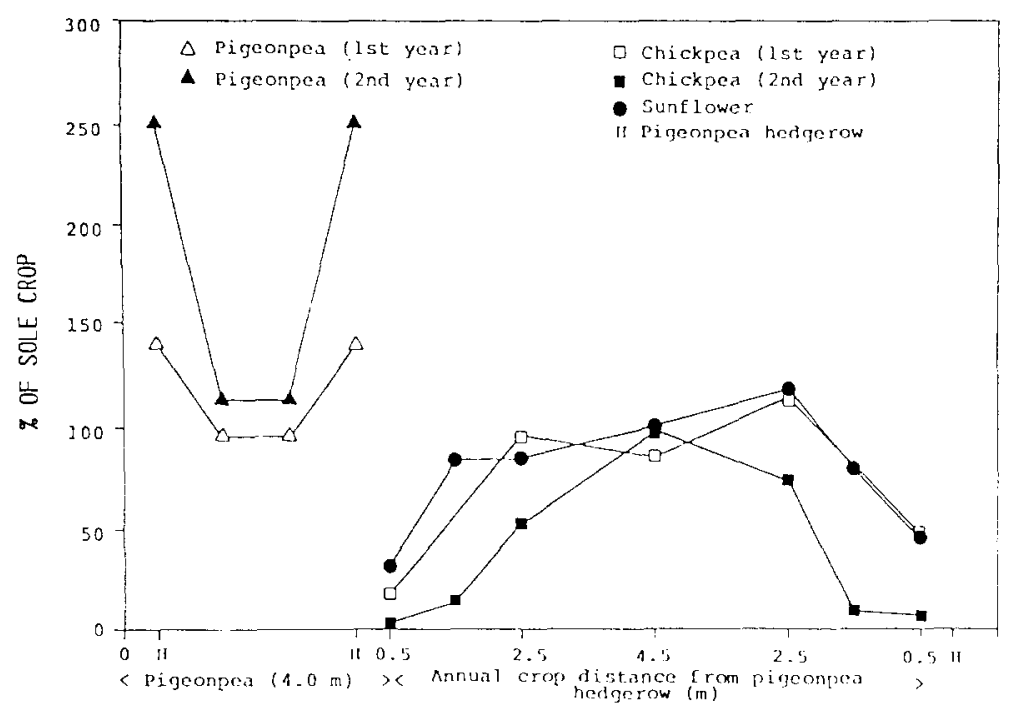

Fig. 4. Interaction between perennial pigeonpea and annual crops: grain yields of perennial pigeonpea and chickpea, and total dry matter of sunflower expressed as a percentage of their respective sole crop yields, ICRISAT center.

0.42 and $2.04 \mathrm{tha}^{-1}$ in the first and second year, respectively. Dry matter and grain production of pigeonpea were significantly higher in strips than in blocks.

Annual crop yields in the study, however, were lower in strip-planting compared to block-planting because of growth retardation adjacent to pigeonpea rows. Growth retardation was negligible beyond $1.5 \mathrm{~m}$ from the base of the pigeonpea plants in the first year and the following rainy season, but was considerably greater in the second postrainy season (Fig. 4). Total production was not significantly different between the planting arrangements as the reduction in dry matter and grain yield in annual crops in strip-planting was compensated for by increased yield of pigeonpea. Although separation of the annual and the perennial species may not be important in terms of yield, it may be beneficial in plant management such as spraying or protection from off-season grazing. Competition in the strips can be reduced by removal of the lower branches of pigeonpea or harvesting for fodder at critical growth stages of the annual crop to reduce competition for light and moisture. If pruning is not possible, it would not be advisable to grow a post-rainy season crop. This should not be a problem where only a single crop is possible as in the case of a shallow or light soil.

Studies at ICRISAT on both Vertisol and Alfisol indicated that perennial pigeonpea behaves like medium duration types in the first year (Table 3), and was probably less competitive to the annual in the system than leucaena. 
Table 3. Comparison of the effect of perennial and medium duration pigeonpea on sorghum and groundnut in intercropping, ICRISAT center

\begin{tabular}{lll}
\hline Crop system & Grain yield & Biomass \\
\hline & & \\
a. $\quad$ Effect of sorghum (CSH 6) & & \\
$\quad$ Sole sorghum & $3.85 \pm 0.35$ & $9.56 \pm 1.28$ \\
$\quad$ Intercrop sorghum:ICP 1-6 & $2.63 \pm 0.14$ & $5.47 \pm 1.27$ \\
$\quad$ Intercrop sorghum:ICP 8094 & $2.64 \pm 0.29$ & $5.79 \pm 0.81$ \\
b. Effect on groundnut (Robut 33-1) & & \\
$\quad$ Sole groundnut & $1.92 \pm 0.34$ & $5.23 \pm 0.88$ \\
$\quad$ Intercrop groundnut:ICP 1-6 & $1.30 \pm 0.09$ & $3.58 \pm 0.14$ \\
$\quad$ Intercrop groundnut:ICP 8094 & $1.22 \pm 0.04$ & $3.98 \pm 0.52$ \\
\hline
\end{tabular}

${ }^{a}$ Sorghum was grown in a 2:1 row arrangement on Vertisol and groundnut in 4:1 row arrangement on Alifsol.

Therefore, a 2:1 row arrangement of sorghum:perennial pigeonpea on Vertisol or 4:1 arrangement of groundnut:perennial pigeonpea on Alfisol can be adopted for the first year with a pigeonpea density of 28,000 plants $\mathrm{ha}^{-1}$. Thus, perennial pigeonpea can be used in existing conventional intercropping systems without modification and economic sacrifice in the first year.

The extent of yield reduction acceptable in the annual crop would determine land allocation for the perennial component in the system. A population of 27,000 plants ha $^{-1}$ of medium-duration pigeonpea was considered optimum for intercropping with sorghum in order to minimize reduction in sorghum yield [30]. Subsequent studies showed that the pigeonpea population of the medium-duration genotype ICP 1 can be increased up to 60,000 plants ha $^{-1}$ without a corresponding decrease in sorghum yields [23]. The optimum population of perennial pigeonpea for agroforestry systems is probably lower than for medium-duration types in intercropping systems. If the survival rate after the first year is good, some thinning can be effected as most perennials increase in size during the second year. Thinning by removal of alternate rows or two out of every three rows in medium-duration genotype ICP 1-6 planted at 300,000 plants ha ${ }^{-1}$ did not result in significant reductions in grain yield or litter fall [5].

As discussed already, pod-bearing in pigeonpea occurs mostly in terminal branches exposed to direct sunlight. The number of barren branches is likely to be greater at higher plant densities. However, the decline in productive branches can be more than compensated for by the increase in plant population. In a comparative study at ICRISAT, most of the perennial genotypes produced more grain and fodder when planted at 330,000 plants ha $^{-1}$ than 
at 28,000 plants ha $^{-1}$ [9]. Grain yield was unaffected by density in the range of 15,000 to 95,000 plants $^{-1}$ in another study comparing four perennial genotypes at ICRISAT, but surprisingly firewood production decreased with increasing plant population because of the reduction in stem diameter [9].

\subsection{Production systems}

Traditionally pigeonpea is sown in June-July in grain-production systems in India [4]. This enables the crop to utilize the monsoonal rains for vegetative growth and the short days that follow for flower induction. After the harvest of the main crop, one or two ratoon crops are taken provided winter is mild and moisture is not limiting. In another system, pigeonpea is sown about two months after the longest day, that is, September-October in the northern hemisphere and March-April in southern hemisphere. Such a system is practised in some parts of peninsular India where cropping is done in Vertisols only during the post-rainy season [20]. In this system, pigeonpea is planted in late-September or early-October, grain is harvested in March, and the crop is ratooned. The profuse vegetative growth resulting from the June rains may be harvested as fodder, and a grain yield obtained from the fresh growth in November. A second ratoon is possible if conditions are favourable. A similar system has been studied with a medium-duration genotype ICP 1-6 [5]. Grain yield in this system was low in the first harvest because of late planting and the third harvest was also small. Therefore, more than $65 \%$ of the total grain yield was obtained from the second harvest.

Perennial pigeonpea-based agroforestry systems can be similar to the above situations. In a study at ICRISAT, perennial pigeonpea was sown in August, a grain yield was obtained in January of the following year, and subsequently three fodder harvests were taken in April, May and July [9]. This cycle can be repeated in the following year. Grain and dry matter production may probably be lower during the first year if planted late, especially at higher latitudes. Sowing after mid-September caused sharp decline in grain yields of long-duration pigeonpea genotypes in north India [25]. Byth et al. [1981] described a grain-production system where photoperiod-insensitive genotypes are sown as soon as soil temperatures are favourable for germination after winter [4]. This system is practised in north India with pigeonpea grown as a sole crop or intercropped with mungbean. The favourable time for planting in this system is during March-April in the northern hemisphere and September-October in southern hemisphere. Perennial pigeonpea can fit into such early plantings as well, provided 
moisture is not a limiting factor. However, flowering may not occur for several months because perennial genotypes are unlikely to be photo-insensitive. A management strategy for this system would be to harvest for fodder until the onset of short days.

\subsection{Harvesting}

Timing and method of fodder and grain harvests should be such that future yields are not affected. Fodder harvests should be done when there is a dry spell during the rainy season. If the field is excessively wet at the time of fodder harvest, the plants can be killed by waterlogging. Multiple fodder cuts are possible when a grain yield is not the objective. Fodder harvest towards shorter days can result in either low or no grain yield because of insufficient vegetative growth when daylength is favourable for flower induction. Different cutting intervals [26] and cutting heights [2] have been investigated and generally $3-4$ cuts and cutting heights of $25-50 \mathrm{~cm}$ have been most productive.

Pods can be hand picked or removed with stems, and the plants pruned back to a suitable height after harvest. Hand picking resulted in earlier flowering and greater number of pods in the second flush than harvesting by cutting branches in a short-duration (4 months) pigeonpea [22]. The lower the pruning height, the smaller were the second harvest yields of a mediumduration pigeonpea [32]. Tayo [1985], however, reported that ratooning at $30 \mathrm{~cm}$ in a dwarf pigeonpea resulted in higher yields than hand picking or ratooning at $60 \mathrm{~cm}$ [31]. Information on appropriate cutting heights for fodder and grain harvest in perennial pigeonpea is lacking.

\section{Research needs}

Information presently available, though limited, establish perennial pigeonpea as a promising species for agroforestry systems. More research is needed on several agronomic aspects and some pertinent areas are listed below.

1. Appropriate canopy management practices and optimum population to minimize competition for moisture, nutrients and light encountered by the annual crops in the system.

2. Productive life of perennial pigeonpea, ratoonability, pruning strategies, pest and disease management.

3. Effectiveness of pigeonpea foliage as a green manure during the rainy season when the demand for fodder is low.

4. Use of perennial pigeonpea as wind breaks and as vegetative barriers in 
soil and water conservation.

5. Residual effects of perennial pigeonpea on the growth of subsequent crops and on soil properties.

6. Use of perennial pigeonpea in the restoration of fertility in degraded soils.

7. Nitrogen fixation under different climates and canopy management practices.

8. Evaluation of different agroforestry systems under different climatic conditions.

\section{Concluding remarks}

This paper has detailed the considerable merits and some of the problems of using perennial pigeonpea in agroforestry systems and has generally ignored the social constraints to adoption by farmers. Unlike the introduction of Leucaena leucocephala or Gliricidia sepium, perennial pigeonpea is already widely grown in south Asia and eastern Africa as a multi-purpose legume crop and its fodder is readily accepted by livestock. However, the introduction of perennial pigeonpea to new regions may suffer from the same adoption problems encountered by grain pigeonpea because the preference for pigeonpea grain is lower than for other grain legumes. The potential of perennial pigeonpea as an agroforestry species was not widely appreciated until recently, even in India. Pigeonpea is easy to establish by direct seeding and can be useful in short rotations as an improved fallow. There is a need to develop appropriate management practices, since the requirement during the second year is different from the annual grain types, and to re-introduce perennial pigeonpea as a multi-purpose species on a wider and more organised scale than hitherto practised in farmers' fields.

\section{References}

1. Ahlawat IPS, Saraf CS, Patil RR and Parshad M (1981) Multiple correlations and regression studies in pigeonpea. Indian Journal of Agronomy 26: 432-434

2. Bahar FA (1982) Cultural practices for pigeonpea (Cajanus cajan (L.) Millsp.) as forage, green manure, and grain crop. Dissertation Abstracts International, B. 43: 10

3. Buranasilpin P (1983) Pigeonpea research in Thailand. International Pigeonpea Newsletter 2: 9-10

4. Byth DE, Wallis ES and Saxena KB (1981) Adaptation and breeding strategies for pigeonpea. Pages 450-465. In Proceedings of the International Workshop on Pigeonpeas. Vol 1, 15-19 Dec, 1980, ICRISAT, Patancheru, AP, India

5. Chauhan YS, Venkataratnam N and Sheldrake AR (1987) A perennial cropping system 
from pigeonpea grown in post-rainy season. Indian Journal of Agricultural Sciences 57: 895-899

6. Gooding HJ (1962) The agronomic aspects of pigeonpeas. Field Crop Abs 15: 1-5

7. Hammerton JL (1971) A spacing/planting date trial with Cajanus cajan (L.) Millsp. Tropical Agriculture (Trinidad) 48: $341-350$

8. ICRISAT (International Crops Research Institute for the Semi-Arid Tropics) (1986) Annual report 1985. Patancheru, AP 502324, India

9. ICRISAT (International Crops Research Institute for the Semi-Arid Tropics) (1987) Annual report 1986. Patancheru, AP 502324, India

10. ICRISAT (International Crops Research Institute for the Semi-Arid Tropics) (1988) Annual report 1987. Patancheru, AP 502324, India

11. International Institute of Tropical Agriculture (IITA) (1980) Annual report for 1979. Ibadan, Nigeria

12. International Institute of Tropical Agriculture (IITA) (1981) Annual report for 1980. Ibadan, Nigeria

13. International Institute of Tropical Agriculture (IITA) (1986) Annual report and research highlights. Ibadan, Nigeria

14. Jain KC, Saxena KB and Faris DG (1987) Performance of medium-duration pigeonpea genotypes for wood and grain yield in pigeonpea. International Pigeonpea Newsletter 6: 34-35

15. Kannaiyan J, Haciwa HC, Greenberg DC, Mbewe MN, Irwing NS and Sohati PH (1988) Pigeonpea research in Zambia. International Pigeonpea Newsletter 7: 12-13

16. Krauss FG (1932) The pigeonpea (Cajanus indicus): its improvement, culture and utilization in Hawaii. Hawaii Agricultural Experiment Station, Bulletin No 64. Honolulu, Hawaii

17. Kumar Rao JVDK, Dart PJ, Matsumoto T and Day JM (1981) Nitrogen fixation by pigeonpea. Pages 190-199. In Proceedings of the International Workshop on Pigeonpeas. Vol 1, 15-19 Dec, 1980, ICRISAT, Patancheru, AP, India

18. Kumar Rao JVDK, Dart PJ and Sastry PVSS (1983). Residual effect of pigeonpea (Cajanus cajan) on yield and nitrogen response of maize. Experimental Agriculture 19: $131-141$

19. Nair PKR (1984) Soil productivity aspects of agroforestry. Nairobi: ICRAF

20. Narayanan A, Murthy SRK and Khader MA (1981) Performance of pigeonpea in the post-rainy season. Pages 209-215. In Proceedings of the International Workshop on Pigeonpeas. Vol 2, 15-19 Dec, 1980, ICRISAT, Patancheru, AP, India

21. Pandey RK (1981) Growth, development and yield physiology of pigeonpea. Pages 203-208. In Proceedings of the International Workshop on Pigeonpeas. Vol 2, $15-19$ Dec, 1980, ICRISAT, Patancheru AP, India

22. Rao MR and Sachan RC (1988) Potential of short-duration pigeonpea for a multipleharvest system. International Pigeonpea Newsletter 7: 14-17

23. Rao MR and Willey RW (1983) Effects of pigeonpea plant population and row arrangement in sorghum/pigeonpea intercropping. Field Crops Research 7: 203-212

24. Reddi KC, Soffes AR and Prine GM (1983) Effectiveness of pigeonpea and other tropical legumes in controlling nematodes in following crops. International Pigeonpea Newsletter 2: $57-58$

25. Roy Sharma RP, Thakur HC and Sharma HM (1981) Pigeonpea as a rabi crop in India. Pages 26-36. In Proceedings of the International Workshop on pigeonpeas. Vol 1, 15-19 Dec, 1980, ICRISAT, Patancheru, AP, India

26. Salih AF (1981) Effect of number of cuts and time of cutting on pigeonpea forage yield. Pulse Crops Newsletter 1: 34 
27. Sharma D and Sowley GK (1984) Comparison of maize/pigeonpea intercropping patterns in Northern Ghana. International Pigeonpea Newsletter 3: 24-25

28. Sharma D, Reddy LJ, Green JM and Jain KC (1981) International adaptation of pigeonpeas. Pages 71-81. In Proceedings of the International Workshop on pigeonpeas. Vol 1, 15-19 Dec, 1980, ICRISAT, Patancheru, AP, India

29. Singh RP, Van Den Beldt RJ, Hocking D and Korwar GR (1986) Alley cropping in the semi-arid regions of India. Proceedings of Workshop on Alley cropping. International Institute of Tropical Agriculture, Ibadan, Nigeria, March 10-14. (In press)

30. Tarhalkar PP and Rao NGP (1981) Genotype-plant density considerations in the development of an efficient intercropping system for sorghum. Pages 35-40. In Proceedings of the International Workshop on Intercropping, 10-13 Jan, 1979, ICRISAT, Hyderabad

31. Tayo TO (1985) Assessment of the effect of ratooning pigeonpea (Cajanus cajan (L.) Millsp.). Journal of Agricultural Sciences, Cambridge 104: 589-593

32. Venkataratnam N and Sheldrake AR (1985) Second harvest yields of medium duration pigeonpea (Cajanus cajan) in peninsular India. Field Crops Research 10: 323-332

33. Wallis ES, Faris DG, Elliott R and Byth DE (1986) Varietal improvement of pigeonpea for small-holder livestock production systems. In Workshop on Crop-Livestock Systems Research, July 7-11, 1986, Khon Kaen, Thailand

34. Whiteman PC and Norton BW (1981) Alternative uses for pigeonpea. Pages 365-376. In Proceedings of the International Workshop on Pigeonpeas. Vol 1, 15-19 Dec, 1980, ICRISAT, Patancheru, AP, India

35. Willey RW, Rao MR and Natarajan M (1981) Traditional cropping systems with pigeonpea and their improvement. Pages 11-25. In Proceedings of the International Workshop on Pigeonpeas. Vol 1, 15-19 Dec. 1980, ICRISAT, Patancheru, AP, India 